\title{
COMPOSITIONAL ANALYSIS AND CROSS-CULTURAL EXAMINATION OF BLUE AND BLUE-GREEN POST-FIRE COLORANTS on Tolita-Tumaco ceramics
}

\author{
Breanna F. Reiss \\ University of New Mexico, College of Fine Arts \\ breiss@unm.edu \\ Michael Spilde \\ https://orcid.org/0000-0002-0693-9049 \\ University of New Mexico, Institute of Meteoritics \\ mspilde@unm.edu \\ Eric Peterson \\ ejpete@unm.edu
}

University of New Mexico, Department of Earth and Planetary Sciences

\section{Resumen}

ANALISIS COMPOSICIONAL Y EXAMINACIÓN INTERCULTURAL DE LOS COLORANTES POSCOCCIÓN AZUL Y AZUL-VERDOSO EN CERÁMICAS TOLITA-TUMACO

Este estudio explora los colorantes azules y azul-verdoso utilizados por la cultura Tolita-Tumaco de las costas antiguas de Ecuador y Colombia. Utilizando la difracción de Rayos X (DRX) y la microscopia electrónica de barrido (SEM) con la espectroscopía de energía dispersiva (EDS), se analizaron muestras de cada uno de los colorantes azul y azulverdoso para identificar las composicións mineral. La muestra azul verdosa de una cerámica encontrada en La Tolita fue identificada como celadonita o glauconita. Las pruebas de DRX y SEM en una muestra azul de un fragmento de figurilla de cerámica encontrado a lo largo del rio Mataje se identificaron tentativamente como los anfiboles sódicos glaucofano y riebeckite. Las pruebas de DRX sugieren además otros minerales que pueden afectar el color, como la cordierita, antigorita y celadonita o glauconita. La comparación intercultural proporciona información sobre cómo los grupos ecuatorianos costeros utilizaron estos colorantes y ejemplifica la naturaleza innovadora detrás de su creación. Parece que el desarrollo de azul y azul verdosa ecuatoriano se derivó de las tradiciones de colorantes locales, con algunas fuentes de pigmentos localizadas.

Palabras clave: Tolita-Tumaco, pigmento, celadonita, glauconita, azul.

\section{Abstract}

This study explores blue and blue-green post-fire colorants used by the Tolita-Tumaco culture of ancient coastal Ecuador and Colombia. Using X-ray diffraction (XRD) and scanning electron microscopy (SEM) coupled with energy dispersive spectroscopy (EDS), one sample each of blue and blue-green colorants taken from ceramic surfaces were tested to identify the mineral compositions present. The blue-green sample from a ceramic sherd found at La Tolita was identified as celadonite or glauconite. XRD and SEM tests on a blue sample from a ceramic figurine fragment found along the Rio Mataje was tentatively identified the sodic amphiboles glaucophane and riebeckite. XRD tests further suggest other minerals that may affect the color, including cordierite, antigorite, and celadonite or glauconite. Cross-cultural comparison provides insight on how coastal Ecuadorian groups used these colorants and exemplifies the innovative nature behind 
their creation. It appears that the development of Ecuadorian blue and blue-green derived from local colorant traditions, with some localized pigment sources.

Keywords: Tolita-Tumaco, pigment, celadonite, glauconite, blue.

\section{Introduction}

Blue is the rarest color in nature and one of the more difficult colors to produce in a form stable enough to be a paintable substance. To make the vibrant blues and blue-greens that decorated ceramics and architecture, ancient artists relied on their own ingenuity and what was naturally available, such as hard to find blue minerals. In ancient Mesoamerica, examples of Maya Blue and blue copper carbonate-based pigments are relatively widespread, but blue and blue-green ceramic colorants in ancient South America are almost non-existent.

Coastal Ecuador during the Regional Development Period (RDP), dating from around $500 \mathrm{BC}$ to $600 \mathrm{AD}$, may be one of the only places in South America where blue and blue-green colorants were used on ceramics. The post-fire blue and blue-green colorants used along the northern coast of Ecuador are notable for their vivid colors and longevity. What materials did the coastal Ecuadorians use to create these colors? Could they hold potential similarities to outside colorant traditions? To address these questions, this research undertakes laboratory testing of samples from collections at the University of New Mexico's Maxwell Museum of Anthropology in Albuquerque, New Mexico.

An archaeologically retrieved sample of two ceramics featuring blue and blue-green colorants from the Tolita-Tumaco culture (600 BC-400 AD) served as the focus of a multidisciplinary methodology. First, X-ray diffraction (XRD) and scanning electron microscopy coupled with energy dispersive spectroscopy (SEM-EDS) were used to determine the mineral composition of these colorants. Secondly, the discussion employs an iconographic analysis and cross-cultural comparison to provide a contextual framework for the testing results.

Coastal Ecuadorian groups during the RDP have received attention from scholars for their advancements in balsa raft creations and evidence of maritime trade, potentially at long distances (Zeidler 1991; Callaghan 2003; Dewan and Hosler 2008; Martín 2010). Early Spanish descriptions report encountering Ecuadorian balsa rafts packed with people and trade goods (Samano [1534] 1987). This evidence, alongside similarities in metallurgy and iconography with Mesoamerica and Peru make the analysis of potential connections worthwhile (Reichel-Dolmatoff 1965; Meggers 1966; Hosler 1988). Cross-cultural analysis is employed to contextualize the Tolita-Tumaco ceramic colorant traditions, ultimately emphasizing the unique qualities of the culture's blue and blue-green post-fire colorants.

The Tolita-Tumaco culture inhabited an area stretching along the coast of Ecuador from the northern Esmeraldas Province to the port city of Tumaco in the Nariño department of southwest Colombia. The first signs of settlement in the area appeared near the mouth of the Rio Santiago around 600 BC (Valdez 1992). Explorations of the hinterland area by William DeBoer and others demonstrate stylistic similarities with the La Tolita site (DeBoer 1996; Valdez 1992). Evidence points to the island site La Tolita as the ceremonial center for this area, with likely relations to some of the surrounding coastal and highland groups in Ecuador and Colombia.

The Tolita-Tumaco culture is perhaps most well-known for technological advancements in metal alloys and miniature metalwork, as well as an elaborate variety of ceramic figural forms frequently painted in post-fire polychrome. Bright shades of red, yellow, orange, green, and sometimes blue were used to color freestanding figurines, as well as those attached to vessels or incorporated into other objects, like ceramic bowl pedestals, and some architectural forms. The Tolita-Tumaco made their colorants by grinding moist pigments into a fine paste (Sánchez-Polo 2018). 
Testing examples of the more difficult to produce colors provides contextual insight into unique production solutions used in creating Tolita-Tumaco high status ceramic goods. Analysis of blue and blue-green colorants, combined with close comparison of test results to other pre-Hispanic Latin American blues and greens, establish the unique character of ceramic colorant traditions of coastal Ecuador during the RDP. It appears that the development of Ecuadorian blue and bluegreen derived from local ceramic colorant traditions.

\section{Sample Description}

Two colorant samples from different sites in the Ferdon collection currently held by the Maxwell Museums of Anthropology were used in this study. Acquired by the Maxwell Museum in 2006 and 2008 from the Museum of New Mexico, the Ferdon collection is a sizable amount of sherds, as well as partial and whole ceramics, stone, bone, metal, shell, and other archaeological materials. Pottery sherds make up the bulk of the collection, and examples of figurines that may be from the early Valdivia culture, as well as a number of small beads, stone axes and celts, and residue samples all remain in need of further study.

The Ferdon collection is from one midden excavation and a number of surface excavations from across coastal Ecuador collected by Edwin Nelson Ferdon Jr., with the help from John Maxwell Corbett on some of the early expeditions. Ferdon made his first trip to Ecuador in 1939 and continued making surface collections in the country until 1943 (Simmons 1970). At that point, he began to help the war effort with missions to retrieve quinine in Ecuador, while still identifying archaeological sites in his journeys far into the Ecuadorian highlands and the Amazon (Lubensky 1991: 4).

Ferdon wrote in unpublished and published reports on his travels within Ecuador (Ferdon and Corbett n.d.; Ferdon 1940a, 1940b, 1941). He also recorded every item he collected on a field sheet, a fact reiterated by Earl Lubensky, a graduate student who had access to these records while working on his dissertation (Ferdon 1940b; Lubensky 1991). Unfortunately, most of the records were not retained with the collection; the pages that do still accompany the collection are recorded in pencil that has faded extensively over the years. However, Ferdon and Corbett's time in 1945 at one of the sites in this study is recorded in an account with minimal detail (Ferdon and Corbett n.d.).

In determining provenance for the Ferdon collections objects used in this study, several factors needed to be considered. Some pieces were inaccurately labeled in museum storage contexts. However, many pieces held Ferdon's original shorthand. For location accuracy, the records on the ceramics themselves and the labels provided by the Maxwell and the Museum of New Mexico were considered. Information from the dissertations of two scholars who worked with the collection was also used: Lubensky (1991) on the Esmeraldas collection and Michael Patrick Simmons on the La Libertad collection (1970). Lubensky in particular provided invaluable information on Ferdon's labeling method.

The first sample was taken from a sherd (Figs. 1-2) identified as originating from the site La Tolita by a label on the ceramic itself. La Tolita (Fig. 3) was inhabited between $200 \mathrm{BC}$ and 400 $\mathrm{AD}$ and is located near the northwest corner of the island La Tola in the Esmeraldas Province. It is a low-lying mangrove swamp in a significantly humid environment with at least thirty-one and as many as forty mounds recorded at the site (Ferdon Jr. and Corbett n.d.; Valdez 1987; Lubensky 1991). Archaeologists interpret La Tolita as a sacred burial ground and a ceremonial center, with evidence of pilgrimage to the site by many local groups (Meggers 1966; Valdez 1987, 1992). The ceramics of La Tolita are similar to those seen elsewhere along the coast during the RDP, with a more focused attention on naturalistic features (Valdez 1992).

The La Tolita sample clay paste is light creamy grey with larger temper particles. The surface of this rim sherd is incised with deep lines and some incised hatching. Blue green colorant (BG5 


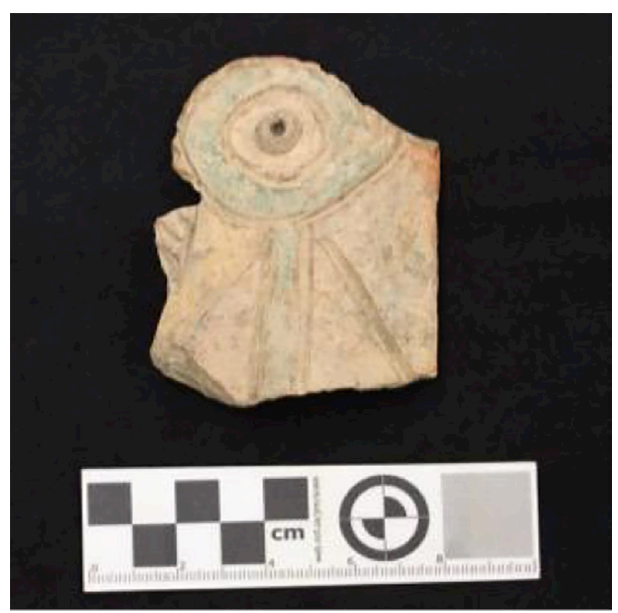

Figure 1. Incised Sherd, La Tolita, Ceramic with Red, Yellow, and Blue-green Post-fire Colorants. Catalogue No: 2006.111.117. Courtesy of the Maxwell Museum of Anthropology, University of New Mexico (Photo by Breanna Reiss).

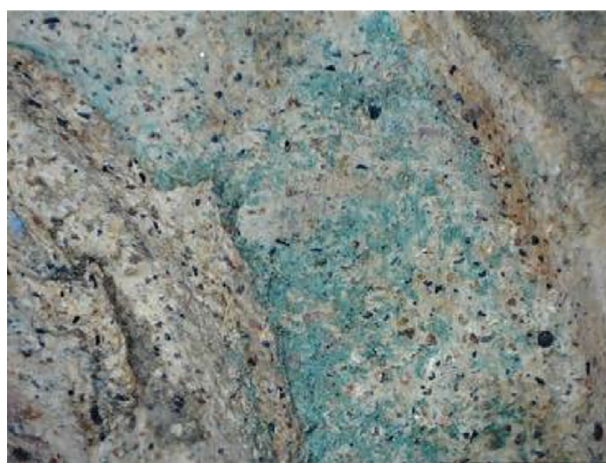

Figure 2: Digital Microscope Image of Incised Sherd, La Tolita, Ceramic with Red, Yellow, and Blue-green Post-fire Colorants. Catalogue No: 2006.111.117. Courtesy of the Maxwell Museum of Anthropology, University of New Mexico (Photo by Breanna Reiss).

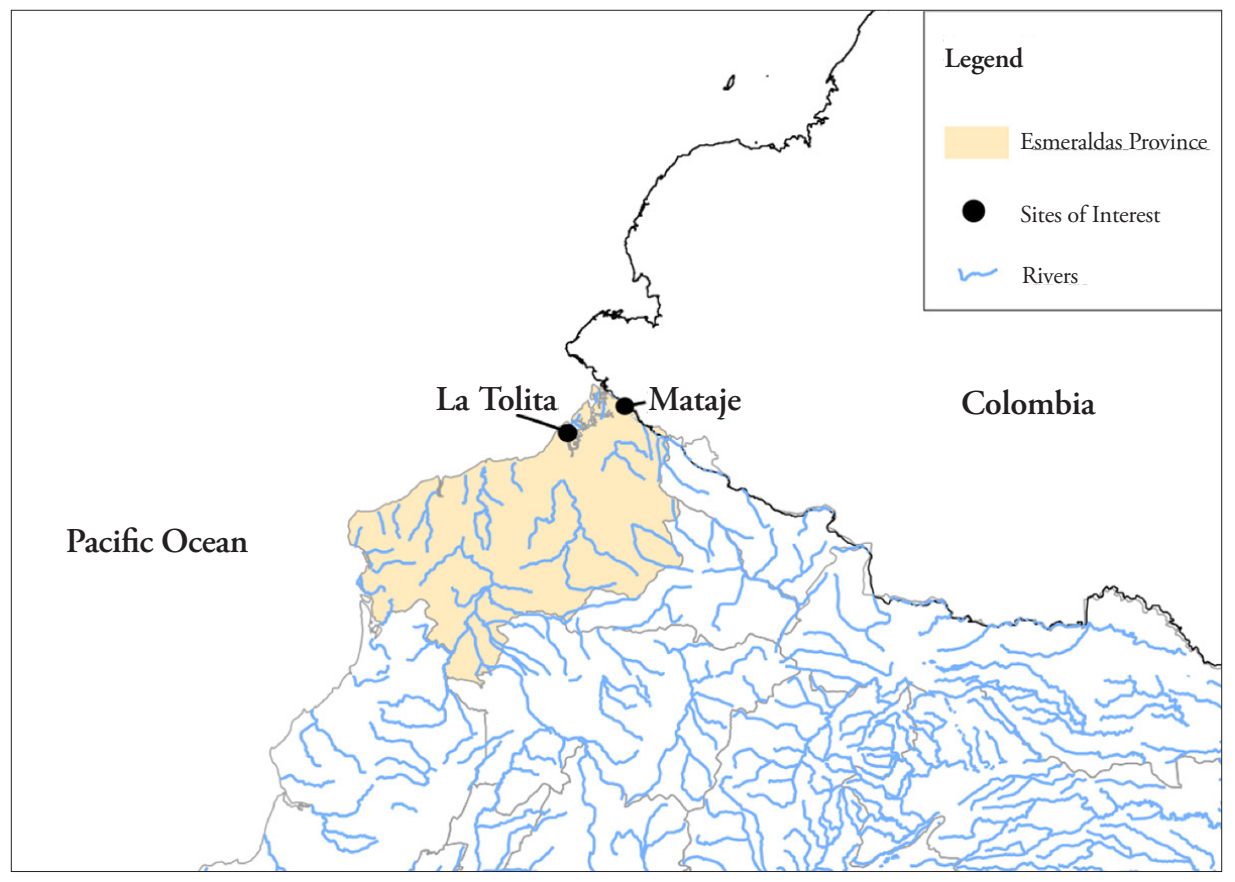

Figure 3. Map of areas where samples were found. The blue sample was found somewhere near the town of Mataje, which is marked on the map (Courtesy of Marcela Moreno). 


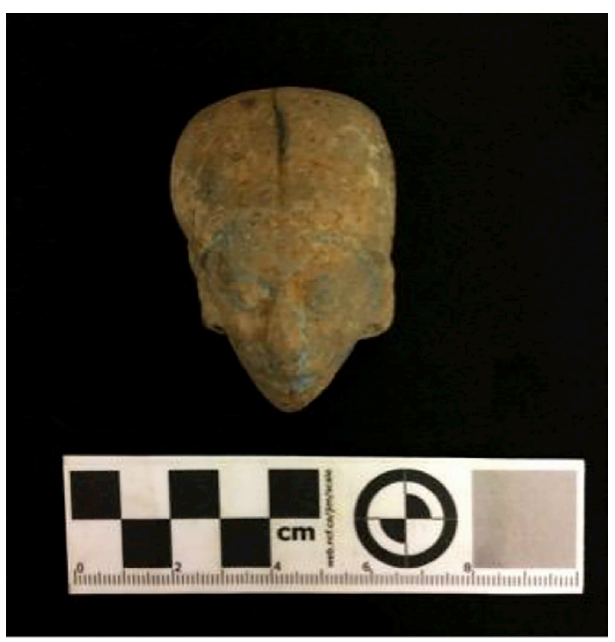

Figure 4. Figurine Head, Rio Mataje Site, TolitaTumaco Culture, Ceramic with Blue Post-Fire Colorant. Catalogue No: 2006.56.49. Courtesy of the Maxwell Museum of Anthropology, University of New Mexico (Photo by Breanna Reiss).

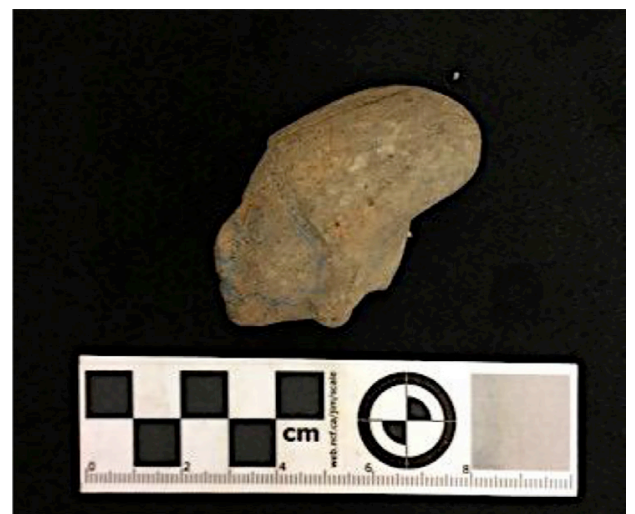

Figure 5. Figurine Head (side view), Rio Mataje Site, Tolita-Tumaco Culture, Ceramic with Blue Post-Fire Colorant. Catalogue No: 2006.56.49. Courtesy of the Maxwell Museum of Anthropology, University of New Mexico (Photo by Breanna Reiss).

$5 / 4)$, is painted within the narrow surface of an incised element. The center of the circle has a small ball of clay pressed onto the surface and shaped into a cone with a single punctation stamped into the center. Remnants of red and yellow post-fire paint are also found on other incised sections.

Interestingly, the sherd is flat, with evidence in the particle arrangement that the piece was made from a slab of clay. The flatness of the piece and the variety found in coastal Ecuadorian ceramic forms make it difficult to suggest the original form associated with the sherd. It may have originated from a square vessel, a flat handle, a base for a figurine, or something else entirely.

The excavation where the sherd was collected lasted ten days (Ferdon and Corbett n.d.). Ferdon and Corbett were sent to the site for a reconnaissance mission reporting on the gold mining operation there by the hacienda La Tolita owner Sr. Donato Yannuzzelli (Ferdon and Corbett n.d.). Yannuzzelli allowed Ferdon, Corbett, and their wives to gather pottery that was discarded by the workers during the gold mining process, which likely originated from the mounds themselves and the surrounding areas, (Ferdon and Corbett n.d.: 6).

The second sample (Figs. 4-5) is from a small figurine head found somewhere along the Rio Mataje (Fig. 3). This piece was likely produced by impression into a mold based on the observations of a seam in the interior. It demonstrates the skilled craftsmanship with naturalistic features characteristic of the Tolita-Tumaco culture. The figurine wears circular earrings, each with a punctuation through the center, and a sizable nose ring. The head is elongated in the back, a trait on many Tolita-Tumaco figurines, referring to the practice of cranial modification among the ancient coastal Ecuadorians (Valdez 1987). Though it is difficult to tell exactly where the colorant was originally applied, it appears that the blue colorant once covered the face from the hairline down to the cheekbone where it curves in towards with mouth.

This sample represents a particularly vibrant blue colorant (B5 5/8), rivaling colorants like Maya Blue in its vivid hue. The clay has a finely ground temper, and the paste appears to be high in iron, considering the red color. Images taken with a digital microscope (Fig. 6) show evidence that the figurine may have been originally covered in an off-white slip, likely to keep the red surface from interfering with the post fire paint. However, thin sections of the ceramic would be needed to confirm this possibility. 


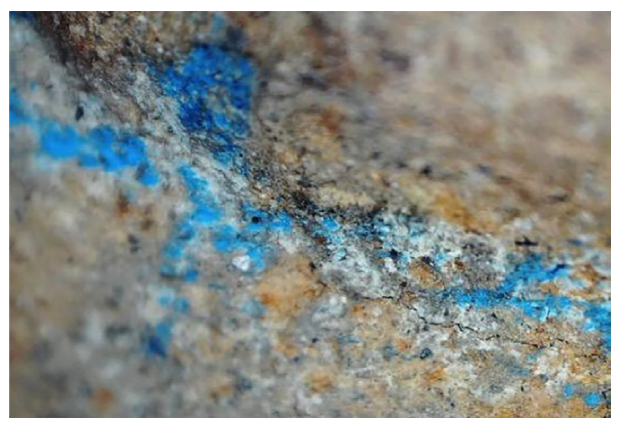

Figure 6. Digital Microscope Image of Figurine Head, Rio Mataje Site, Tolita-Tumaco Culture, Ceramic with Blue Post-Fire Colorant. Catalogue No: 2006.56.49. Courtesy of the Maxwell Museum of Anthropology, University of New Mexico (Photo by Breanna Reiss).

Provenance information for this figurine was found on the original accompanying label, which suggests that it was collected along the Rio Mataje. The Rio Mataje demarcates the line between Ecuador and Colombia for almost half its distance. There is one known site outside the town Mataje near the river mouth where it opens into the Pacific Ocean. Reichel-Dolmatoff mentions a mound of midden more than three meters long near the town Mataje with dates as early as 300 BC (1965: 114).

Reichel-Dolmatoff offers radio carbon dates creating phases for this site, with Mataje I ending in $400 \mathrm{BC}$, and Mataje II beginning in $300 \mathrm{BC}$ and lasting until $10 \mathrm{AD}$, with the sequence unknown for Mataje III (1965). Julio Cesar Cubillos (1955) also mentions the Rio Mataje as a source of excavation, but does not specify the location of the site. The other objects in the Ferdon collection associated with the Rio Mataje site include more ceramic figurine heads and a small quadruped. All of these pieces were reflective of the larger Tolita-Tumaco style by their stylistic traits.

Complete provenance information is difficult to achieve for this piece, as no indication made on Ferdon's map of the journey shows that the Rio Mataje was an area where he travelled (Ferdon 1940b). FerdonandCorbettheaded southwest to the GuayasProvinceafter theirtimeatLaTolita, whichwasthe closestFerdon'sexcavationsappear tohavebroughthim totheColombian border(Ferdon 1940b:259). The identifying markings on the piece are consistent with Ferdon's labeling method. The piece may have come from his time spent in the Esmeraldas Province or it could have been collected in his later travels.

\section{Experimental Methods}

Eric Peterson in the Earth and Planetary Sciences XRD Lab performed X-ray diffraction tests and analyses, and SEM-EDS tests and data interpretations were performed by Michael Spilde in the Institute of Meteoritics SEM Lab. Both labs are located at the University of New Mexico. For the XRD analysis, the La Tolita sherd was first tested intact on a Rigaku D/Max Rapid II diffractometer, in an effort to obtain non-destructive, spatially-resolved diffraction data. Results from this method of analysis were inconclusive.

Using a micro scalpel, small samples $(-20 \mathrm{mg})$ were scraped off of each ceramic surface. These samples were placed on a quartz zero background holder for XRD testing on a Rigaku SmartLab diffractometer. To avoid losing any weight on the small amounts of each colorant, the samples were not ground, resulting in poor diffracted intensity sampling statistics. To compensate for this and provide a better diffraction space sampling, the samples were then placed onto a Eulerian cradle and oscillated in the chi and phi angles while performing multiple theta/two theta scans. Ten theta/two theta scan data sets collected from each sample were then combined to provide a final pattern that was more representative of a randomly-oriented powder.

The samples were then each attached to double-sided carbon tape on a specimen stub and carbon coated. Using a Tescan Vega 3 scanning electron microscope with attached IXRF energy 


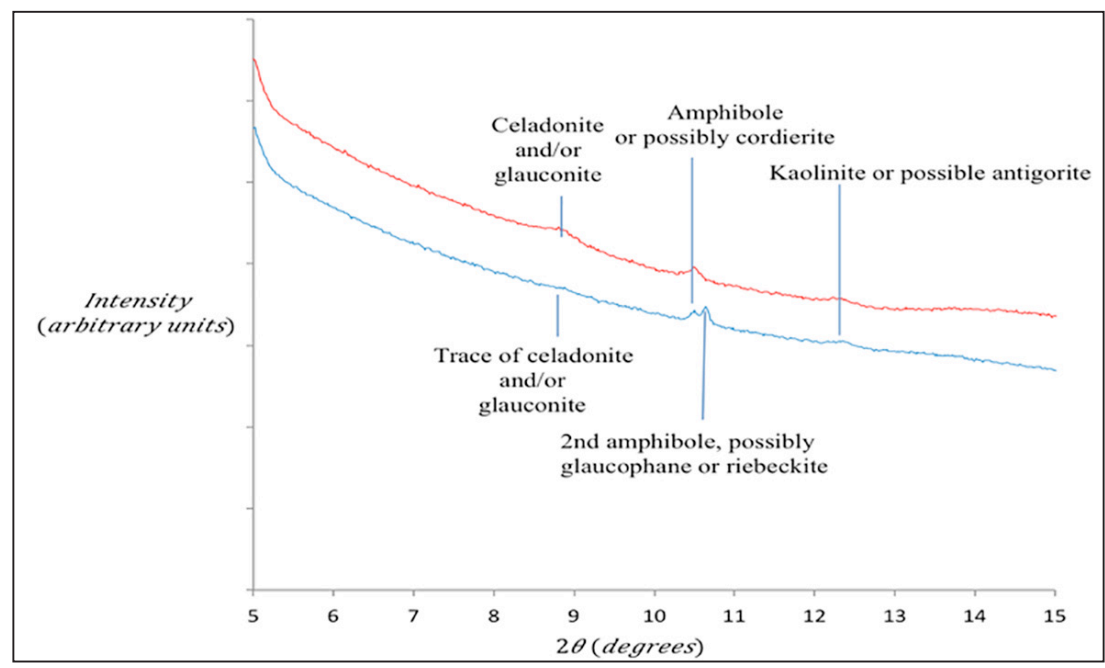

Figure 7. Diffractogram of Samples: the red line represents the La Tolita sample and the blue line is Rio Mataje sample.

dispersive X-ray analyzer, a series of point analyses were performed using imaging with backscattered electrons and element mapping to provide further information on points of interest. Measurements were made with an acceleration voltage of $15 \mathrm{kV}$ and beam current of 1 nanoamp.

\section{Results}

XRD results for the La Tolita sample demonstrated several clear peaks corresponding to the phyllosilicate minerals celadonite or glauconite (Fig. 7). Clay, which is possibly kaolinite, quartz, and an amphibole group mineral were also found in XRD tests of the sample. The SEM point analyses demonstrated the presence of a magnesium-iron-aluminum phyllosilicate with high levels of potassium, consistent with either celadonite or glauconite (Fig. 8).

Element mapping and imaging with backscattered electrons showed a relatively homogenous sample of phyllosilicates and amphibole minerals. Together, the two tests indicate that the bluegreen color originates from celadonite or glauconite. These minerals are closely related and indistinguishable using XRD and SEM-EDS testing methods.

The Rio Mataje blue (B5 5/8) XRD results (Fig. 7) exhibited a weak peak where the diagnostic celadonite or glauconite peak would be expected. A sodic amphibole, possibly glaucophane or riebeckite was identified. Cordierite, a magnesium-iron-aluminum cyclosilicate, and antigorite, a common serpentine mineral, were also identified. All of these minerals have the potential to be responsible for the adding color in the range of green to blue, but their identifications are only tentative. The presence of the clay mineral, kaolinite, in lieu of antigorite is also possible, having a major peak at the same location as the antigorite peak. White koalinite clay may have been used to further alter the final color.

SEM results showed amphibole group minerals (Fig. 9), clay, one instance of a mineral containing the rare earth metal cerium, and one pyrite inclusion. The quantitative data for one of the amphiboles (Table 1) may show a calcic amphibole, like hornblende or ferro-chloro-pargasite. However, it contains iron and sodium, which could suggest that it is riebeckite intergrown with another calcic mineral, or impure riebeckite. Though the results of the two tests did not directly verify one another, they demonstrate that a particularly blue amphibole may be responsible for the Rio Mataje sample's color. 


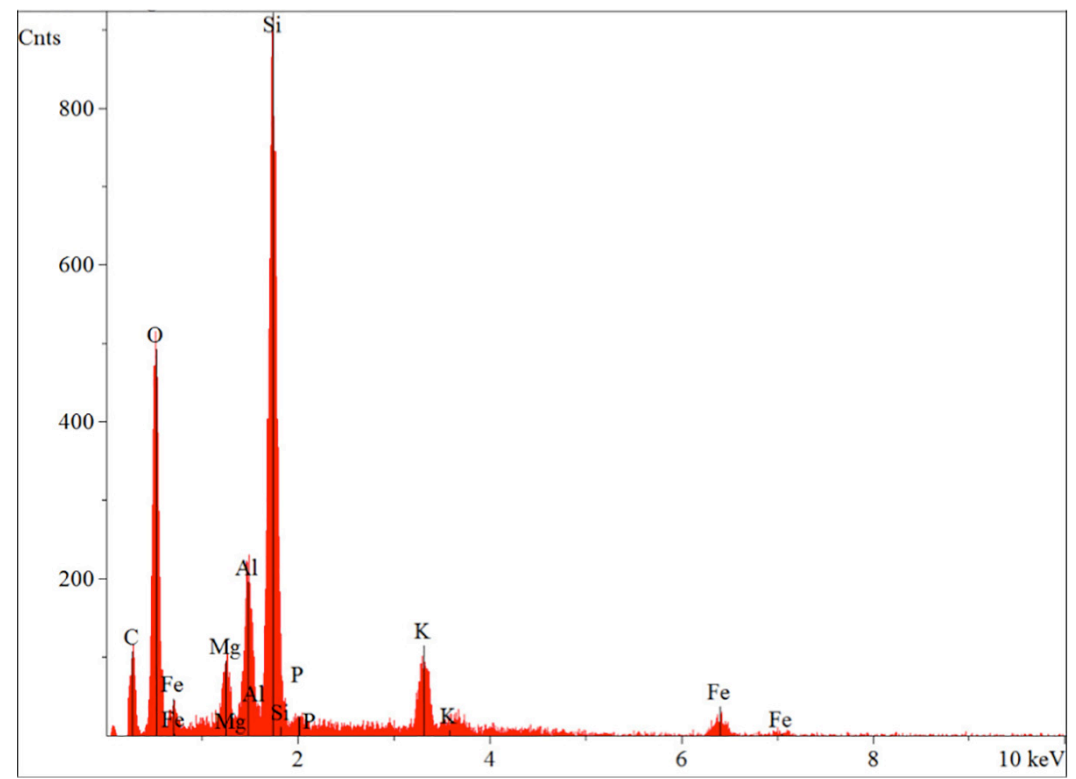

Figure 8. SEM-EDS Spectral Data on La Tolita sample: composition is consistent with celadonite or glauconite. X-ray energy in kilo-electron volts is provided in the $X$-axis and $Y$-axis is $X$-ray counts.

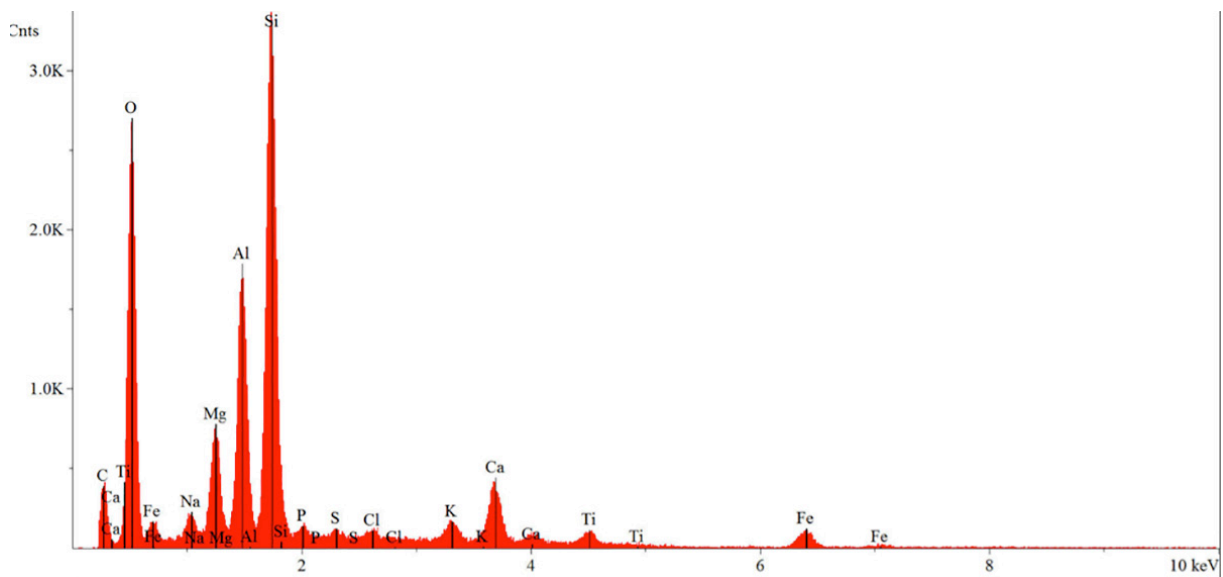

Figure 9. SEM-EDS Spectra Data on Rio Mataje Sample: Amphibole. 


\begin{tabular}{|l|c|c|c|c|c|c|c|c|c|c|c|c|}
\hline Spectrum & $\mathrm{O}$ & $\mathrm{Na}$ & $\mathrm{Mg}$ & $\mathrm{Al}$ & $\mathrm{Si}$ & $\mathrm{P}$ & $\mathrm{S}$ & $\mathrm{Cl}$ & $\mathrm{K}$ & $\mathrm{Ca}$ & $\mathrm{Ti}$ & $\mathrm{Fe}$ \\
\hline $\begin{array}{l}\text { La Tolita } \\
\text { Celadonite }\end{array}$ & 47.04 & n.d. & 2.20 & 6.07 & 31.28 & 0.57 & n.d. & n.d. & 5.88 & 0.88 & n.d. & 6.08 \\
\hline $\begin{array}{l}\text { Rio Mataje } \\
\text { Amphibole }\end{array}$ & 45.15 & 1.51 & 4.62 & 10.65 & 21.67 & 0.56 & 0.32 & 0.61 & 1.77 & 5.66 & 1.62 & 5.88 \\
\hline
\end{tabular}

n.d.= not detected

Table 1. Concentration of major elements (wt\%) within the samples.

\section{Discussion}

The La Tolita blue-green sample was determined to be celadonite or glauconite, which are known as the most common minerals used in "green earth" pigment. Green earth is a collection of siliceous minerals that are commonly used as pigments in many cultures worldwide (Grissom 1986). It comes in shades of pale green, greyish green, and pale blue-green. Originally used to define the typically green pigments used by the Renaissance painters, green earth has many possible mineral sources and a range of color possibilities that are dependent on sources and binders (Grissom 1986).

The term "green earth" is somewhat problematic, as the minerals associated with the colorant often have grey and blue tones as well. It is, however, difficult to distinguish between celadonite and glauconite with most methods of testing, making green earth an unfortunately vague, but necessary, term. "Green earth" is here used to specifically describe celadonite and glauconite. In instances where the exact mineral is known, further clarification is offered.

The mineral name celadonite derives from the French céladon, meaning sea green. Glauconite originates from the Greek term, glaukos, which describes a bluish-green or a green-grey. The difference between these minerals is their formation; glauconite is a mineral of marine origin, whereas celadonite is of altered volcanic origin (Grissom 1986). These minerals cannot be heated to ceramic firing temperatures and retain their color; heated celadonite and glauconite in particular turn a burnt umber (Grissom 1986). Their inability to retain their original color during firing may have made them more desirable in pre-Hispanic Latin America as an architectural or rock art pigment, rather than a ceramic colorant.

Reported equivalents of Munsell color hues for green earth range from 2G to 8G, values from 2.7 to 3.0, and chromas from 1.0 to 1.5 (Grissom 1986: 145). The sample itself has a hue of 5BG, values ranging from 5-6, and a chroma of 4 . These results range more towards the blue-green hue and are lighter in value with more saturation to the color, which may suggest the presence of other unidentified additives. However, the recorded ranges offered by Grissom also seem rather low in value in comparison to some dry green earth pigment samples.

Although it is not certain that all or the majority of Ecuadorian blue-green and green colorants contain green earth, another study has further showed the potential for celadonite and glauconite to be the source for green and blue-green ceramic colorants along the Ecuadorian coast (Romero et al. 2018). A team of researchers tested pigments from the northern Ecuadorian coastal groups in the Precolumbian Museum of Art Casa del Alabado collections in Quito (Romero et al. 2018). Researchers found glauconite in four green samples, three of which are associated with the JamaCoaque culture, and one from the Tolita-Tumaco (Romero et al. 2018).

Green and blue-green post-fire colorants were used with some frequency on coastal Ecuadorian ceramics and are often found on figural imagery, though they can also be seen on ceramic house forms and other pieces, like the sherd tested in this study. Light blue-green colorants appear on objects attributed the earlier Chorrera Period (1200-300 BC) (Cummins 1992). The color may 


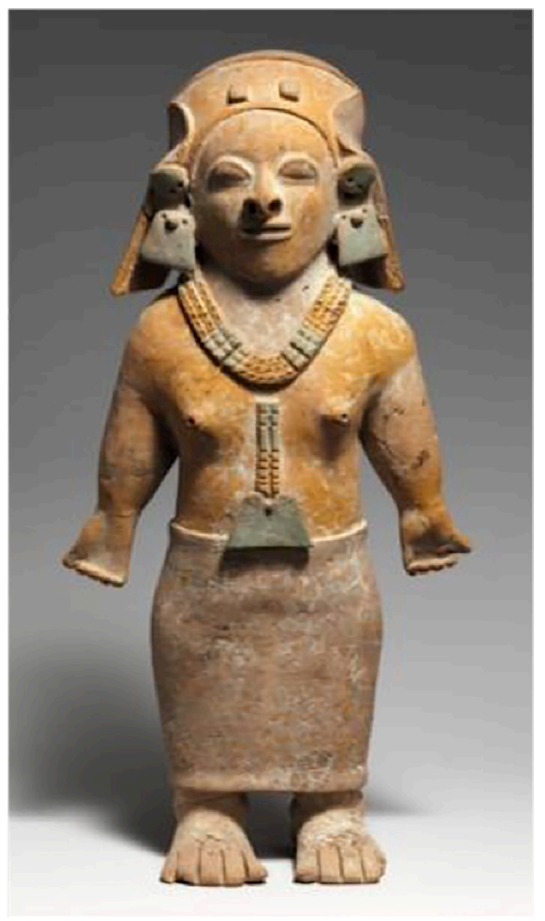

Figure 10. Standing Female Figurine, Jama-Coaque, Ceramic with Polychrome Post-Fire Colorants. The Metropolitan Museum of Art.

hold political and ideological significance as it is often found in association with representations of elaborately dressed figurines. These figures are associated with many different actions and regalia and were often painted in post-fire polychrome (Meggers 1966; Cummins 1992; Valdez 1992). The trend of creating hollow polychrome ceramic figurines lasted for many centuries (Valdez 1987).

Painted on some of the coast's finest ceramic examples, blue-green and green held an important role in the representations of particular events and characters. For example, one type of female figurine (Fig. 10) in particular commonly found across the Ecuadorian coast has consistent associations with these colors. This type of figurine is frequently painted with green and blue-green colorants in the Jama-Coaque and Tolita-Tumaco traditions, with the example shown here from the Jama-Coaque culture.

Ancient ceramists utilized several defining stylistic features to make this figurine recognizable. Betty Meggers (1966) first pointed out this type of female figurine as a stylistic trope used across the coast. The figurine is most commonly freestanding in a static pose with her hands down by her sides and palms facing outward (Meggers 1966). Her mouth is often open, sometimes displaying teeth, and her head is occasionally tilted upwards.

This static female figurine most commonly wears a long skirt and a similar head cloth or headdress that appears to wrap around the head. The jewelry and other ornamentation have more potential variety. Finer examples of these figurines are frequently painted with blue-green and green colorants on the skirt, head cloth, and jewelry. In particular, the color is found painted as a striped or checked pattern on skirts, and painted on a diagonal line along the head cloth.

In general, green and blue-green colorants are often found on what appears to be beadwork attached to the arms, legs, and necks of figurines, perhaps representing some form of stone or oxidized copper. The relationship that blue and blue-green colorants have with the figural form is unknown, and little research has been done into color associations on the coast (Sánchez-Polo 2018). It appears that green and blue-green were used as a reflection of costume elements used in real performances or displays, which may hold ideological and ritual associations. 
Considering that green and blue-green are relatively common on these ceramics, the source, or sources, were most likely local and abundant enough to allow for centuries of use. The closest known source that contains celadonite and glauconite is the Cayo Arc, a geological formation extending from the coast of the Manabí Province southeast into the Bay of Guayaquil (Morante Carballo 2004; Machiels et al. 2014). Celadonite is also found much further inland in the Fruta del Norte deposit in the Zamora-Chinchipe Province (Lipiec et al. 2016). With the proximity of celadonite and glauconite source material, and if the majority of the coastal green and blue-green colorants contain green earth, then the pigment likely originated from local sources within the Cayo Arc. The Cayo Arc source is further suggested in the research associated with the Museum of Precolumbian Art Casa del Alabado collections (Romero et al. 2018).

There are no known sources of celadonite and glauconite within the Tolita-Tumaco cultural area, suggesting that these pigments or the objects bearing the colorant were obtained from elsewhere. The Jama-Coaque culture further south in the Manabí Province would have been the closest group with access to green earth deposits. With the connections between these cultures seen in the archaeological evidence, this finding further demonstrates the likelihood of trade and interaction between the Tolita-Tumaco and Jama-Coaque (Meggers 1966; Masucci 2008; Valdez 1987).

Cross-cultural comparison demonstrates how rarely green earth is found as a ceramic colorant. In pre-Hispanic Latin America, instances of green earth's usage are somewhat sporadic. Outside of the Ecuadorian coast, green earth may be most commonly used in pre-Hispanic Latin America as an architectural and rock art colorant.

At the archaeological site Copan in Honduras, Rosemary Goodall and her team (2006) found that a green paint covering the exterior or the well-preserved Rosalila building contains celadonite. The Maya used white calcite stucco underneath the paint to brighten the shade, and added finely ground magnetite to alter the color (Goodall et al. 2006). A panel holding a stucco mask sampled for Goodall's study showed over twenty layers of paint, demonstrating that the mask had been repainted over the century (520-655 AD) that the Rosalila building was maintained. In a rare example of green earth used as a post-fire ceramic pigment in pre-Hispanic Latin America outside of the Ecuadorian coast, the pigment was found on polychrome pseudo-cloisonné ceramics from La Quemada in western Mexico (Strazicich 2002).

The coastal site of Pachacamac in Peru is one of the few areas in South America where green earth has been identified (Lujan 2018). Known to have been inhabited at different points by the Wari, Lima, Ychma, and Inca cultures, Pachacamac shows evidence of longstanding pilgrimage centered around a wooden oracle thought to hold great power. Building B15, also known as the Painted Temple (900-1300 AD), has several polychrome murals. Researchers have identified a pale green colorant at the Painted Temple as ferroceladonite, an iron rich form of celadonite, but it is sparingly used at the site (Lujan 2018).

A green clay that could also be tentatively identified as green earth through its chemical composition was used on much older murals at Huaca Ventarrón (2300-2035 BC) in the Lambayeque Valley of Northern Peru (Wright et al. 2015). Likewise, it is found to have early dates as rock art pigment in South America. In Argentina, green earth has been identified on rock painting in cave shelters at several early hunter-gatherer sites (Aldazabal et al. 2018; Boschin 2011; Rousaki et al. 2017; Wainwright et al. 2000).

Across pre-Hispanic Latin America, green earth has a variety of uses, but it seems that coastal Ecuador is one of the few places where it is found as a post-fire ceramic pigment. Perhaps this frequency is best explained by the localized nature of the source. Other factors, like an innovative binder or post-fire treatment of the colorant, may also affect the colorant's longevity and allow for its prolonged presence. The sherd found at La Tolita exhibits differences in colorant degradation; the red and yellow colorants on the piece are almost completely degraded, whereas the blue-green pigment remains more intact. Investigations into potential binders and production methods for 
Tolita-Tumaco green earth pigment will likely further show the innovative nature of this unique colorant tradition.

SEM results for the Rio Mataje blue sample show with some certainty that no copper is present in the blue sample, which rules out many possible blue minerals. Many of the popular and sporadic blue colorants used in pre-Hispanic Latin America contained copper. Manmade creations like Maya Blue aside, the most common blue pigment used in pre-Hispanic Latin America may be azurite, a copper carbonate. Teotihuacan used azurite for murals and stuccoed polychrome ceramics, the Maya occasionally used it on murals as well, and it is also found in Peru at Chan Chan on Huaca Tacaynamo murals, and Paracas resin painted pottery (Brooks et al. 2008; Fletcher 2002; de la Fuente 1995; Magaloni et al. 1995; Proulx 2009).

Many more sporadic examples across the Americas have also been shown to contain copper. For example, colorants found on objects in the royal tombs of the Maya site Calakmul were made of the copper-zinc phosphate, veszelyite (Moreno et al. 2008). Perhaps further testing of Ecuadorian post-fire blue colorants will provide insight into their exact composition, but our research shows it is not made from the many copper-containing blue minerals.

The Rio Mataje sample XRD tests instead identified the sodic amphiboles glaucophane and riebeckite, both of which have the potential to be responsible for the blue color. Antigorite, a serpentine mineral, was also identified on XRD, but it has a range closer to green and blue-green in color. Compared to the Rio Mataje sample that exhibits no green hues, it seems the least likely colorant. If this blue colorant derives its color from any of the minerals found in the results, it may be the first known use of these minerals as ceramic colorants in pre-Hispanic Latin America. The peak identified as Antigorite on the diffractogram can alternatively be identified as kaolinite, a more likely option considering the sample's color.

However, none of these minerals were clearly identifiable in SEM testing. The sodic amphibole riebeckite was only tentatively identifiable with the quantitative data gathered in SEM point analyses, but the potential of riebeckite and glaucophane as colorants can be further examined. Frescos and ceramics with both glaucophane and riebeckite, often mixed with Egyptian Blue, have been found at several Bronze Age Greek sites, but they are uncommon outside of that particular time and space (Aloupi et al. 2000; Profi et al. 1977). The blue present on the Rio Mataje sample is brighter than the typical sodic amphibole-produced blue, which may signify other unidentified additives. The closest potential source for glaucophane is in the El Oro Province in Southern Ecuador (Aspden 1995). There are no known sources for riebeckite close to the Tolita-Tumaco area in Ecuador or Colombia.

It is possible that the Ecuadorians traveled some distance to obtain pigments, considering their maritime skills and known evidence of pigment exchange mentioned in this study and elsewhere (Sánchez-Polo 2018; Romero et al. 2018). For instance, white kaolinite pigment used on ceramics amongst the Jama-Coaque may have originated from southeast Ecuador (Romero et al. 2018). A study conducted on ceramics at the Precolumbian Art Museum Casa del Alabado demonstrated that three out of four white ceramic colorants from the Jama-Coaque contained kaolinite clay, whereas the other was made of calcite (Romero et al. 2018). Tentatively identified in XRD tests in the Rio Mataje and La Tolita samples, it is possible that the Tolita-Tumaco ceramists used kaolinite as well. In contrast to the Jama-Coaque area, where the clay was used to produce a white pigment, kaolinite may have been added to make the overall colors lighter on the Tolita-Tumaco ceramics tested in this study.

Past studies of Ecuadorian blue and green colorants have also shown modern colorant additives, like phthalocyanine blue, thought by the researchers to be a product of past restoration attempts (Sánchez-Polo et al. 2018). The results in this study do not demonstrate signs of modern repainting attempts. Alternatively, they show potential mineral sources for the colors, suggesting that not all blue post-fire colorants found on coastal Ecuadorian ceramics are the result of later 
additions and restoration. Use of blue colorants was much more sporadic than other colors along the RDP Ecuadorian coast, possibly as a result of source material rarity.

\section{Concluding Remarks}

Blue and blue-green post-fire colorant samples from ceramics associated with the Tolita-Tumaco culture were tested using SEM-EDS and XRD in conjunction with contextual and cross-cultural analyses. The blue-green sample from La Tolita was shown to contain celadonite or glauconite. These are the main minerals used to create the pigment "green earth".

The use of green earth is not commonly seen as a pigment elsewhere in the pre-Hispanic Latin America, with only a handful of identified examples on both continents. Known to have been used as a colorant mainly for rock art and architecture, this pigment was rarely used on ceramics. Further testing will be necessary to confirm whether the many similar shades of blue-green and green colorants used on ceramics along the southern Colombian and northern Ecuadorian coasts are also the result of a celadonite or glauconite base. Currently, all four green samples from another study and one blue-green sample from this study demonstrate the use of green earth as a post-fire pigment within the Jama-Coaque and Tolita-Tumaco ceramic traditions (Romero et al. 2018).

It is likely that coastal Ecuadorians used localized sources to obtain green earth, considering the close proximity of a potential source in the Cayo Arc (Morante Carballo 2004; Machiels et al. 2014). The closest access point to the Cayo Arc is within the Manabí Province, suggesting the potential for trade relations with the Jama-Coaque culture. However, the exact mineral deposit, or deposits, where green earth was extracted have not been found, and the source could also be from the Cayo Arc's extension into the Bay of Guayaquil, or from a deposit further inland (Lipiec et al. 2016).

Within the Tolita-Tumaco and Jama-Coaque cultures, green and blue-green colorants were used as a post-fire addition of color on particular ceramic characters. Figurines and figural objects where these colorants are found display elite status associations, and the colors were used on figurines for certain clothing aspects, like jewelry, headdresses, and skirts. The use of highly fugitive post-fire paints on ceramic figurines, which are sometimes attached to whistling vessels or made into vessels themselves, suggest that these objects were occasional or single use objects. As other scholars have proposed, ceramic figurines in northern Ecuador appear to have ideological and high status associations behind their production and use (Cummins 1992; Valdez 1992).

Although the sample size here is too small for definitive claims, this study brings forth contextual information associated with the use of green earth through observable similarities on Ecuadorian post-fire colorants, and the availability of the resource. Cross-cultural analysis and iconographic analysis add information on how green and blue-green colorants were used on northern coastal Ecuadorian figurines, providing avenues of future research and insight into stylistic uses of colorants in the region.

There are many potential avenues for further research with Ecuadorian green earth pigment, including possible organic and mineral additives for color alteration and binders. Potential binders are unknown, but the blue-green pigment sample tested here was well adhered to the ceramic surface, and was much less fugitive than the red and yellow colorants present. Celadonite and glauconite are considered to be suitable bases for many other organic and mineral colorants (Grissom 1986).

The results for the Rio Mataje blue colorant were not entirely conclusive. The findings are included in this study to bring insight into an instance of technical skill and variety of post-fire colors from the Pre-Hispanic Latin Americas. The SEM results offered here suggest that the blue does not contain copper, which is in direct contrast to many of the blue colorants used in pre-Hispanic Latin America.

Instead, the XRD and SEM results tentatively demonstrate that the blue colorant could originate from a sodic amphibole, like glaucophane or riebeckite. Additionally, the serpentine mineral, 
antigorite or kaolinite clay, and cordierite, a cyclosilicate, are potential mineral colorants identified in XRD tests. With the exception of kaolinite, these minerals are not frequently found as colorants. Future sampling of Ecuadorian blue ceramic colorants could produce interesting results.

The findings of this study express the uniqueness of ceramic colorant traditions used in coastal Ecuadorian RDP cultures. Despite knowledge that these cultures were historically involved in long distance maritime trade, evidence suggests that ceramic colorant traditions associated with the Tolita-Tumaco were independently developed in the region. In the case of the blue-green pigment made of celadonite or glauconite, it seems that local resources associated with related cultures nearby were used to create the colorant.

\section{Acknowledgements}

We would like to thank the University of New Mexico's Maxwell Museum of Anthropology for allowing us to work with their collections and UNM's College of Fine Arts for providing funding for this study. In addition, we greatly benefited from discussions with Alejandra Sánchez-Polo on her recent research into coastal Ecuadorian colorants with the Precolumbian Museum of Art Casa del Alabado collections. Marcela Moreno's assistance in creating a map for this publication is greatly appreciated. We also appreciate the manuscript edits provided by Isabelle Druc and Margaret Jackson, and Karen Miranda Rivadeneira for her help with translating the abstract.

\section{REFERENCES}

Aldazabal, V., M. Silveira, G. Custo and M. Ortiz (2018). Colors on the north shore of Lago Traful, Neuquén, Argentina, Boletín Del Museo Chileno de Arte Precolombino 19(2), 95-105. https://doi.org/10.4067/S071868942014000200006

Aloupi, E., A.G. Karydas, and T. Paradellis (2000). Pigment analysis of wall paintings and ceramics from Greece and Cyprus. The optimum use of X-ray Spectrometry on specific archaeological issues, X-Ray Spectrometry 29(1), 18-24. https://doi.org/10.1002/(SICI)1097-4539(200001/02)29:1\%3C18::AID-XRS397\%3E3.0.CO;2-5

Aspden, J.A., W. Bonilla and P. Duque (1995). The El Oro metamorphic complex, Ecuador: Geology and economic mineral deposits. Overseas Geology and Mineral Resources 67, 63.

Boschin, M. T. (2011). Chemical and mineralogical analysis of Argentine Patagonian Rock Paintings: A Multidisciplinary Reading, L'Anthropologie 115 (3-4), 360-383.

Brooks, W. E., V. Piminchumo, H. Suárez, J. C. Jackson, and J. P. McGeehin (2008). Mineral pigments at Huaca Tacaynamo (Chan Chan, Peru), Bulletin de l'Institut français d'études andines 37(3), 441-450.

Callaghan, R. (2003). Prehistoric trade between Ecuador and West Mexico: A computer simulation of coastal voyages, Antiquity 77 (298), 796-804. https://doi.org/10.1017/S0003598X00061731

Cubillos, J. C. (1955). Tumaco (notas arqueologicas), Editorial Minerva LTDA, Bogotá.

Cummins, T. (1992). Tradition in Ecuadorian Prehispanic Art: The Ceramics of Chorrera and Jama-Coaque, in: F. Valdez, D. Veintimilla, and M. Reyes (eds.), Amerindian Signs: 5,000 Years of Precolumbian Art in Ecuador, Quito.

DeBoer, W. (1996). Traces Behind the Esmeraldas Shore, University of Alabama Press, Tuscaloosa.

Dewan, L. and D. Hosler (2008). Ancient Maritime Trade on Balsa Rafts: An Engineering Analysis, Journal of Anthropological Research 64(1), 19-40. https://doi.org/10.3998/jar.0521004.0064.102

Ferdon Jr., E. N. (1940a). Reconnaissance in Esmeraldas, Palacio 46, 257-72.

Ferdon Jr., E. N. (1940b). The Archaeological Survey of Ecuador, Palacio 47(6), 138-43.

Ferdon Jr., E. N. (1941). Reconnaissance in Esmeraldas, Palacio 49(1), 7-15.

Ferdon Jr., E. N., and J. M. Corbett (n.d.). Archaeological Investigation of La Tolita, Esmeraldas, unpublished manuscript, July 1945, Maxwell Museum of Anthropology Archives, Albuquerque.

Fletcher, J. M. (2002). Stuccoed tripod vessels from Teotihuacán: An examination of materials and manufacture, JournaloftheAmericanInstituteforConservation41(2),139-154.https://doi.org/10.1179/019713602806112940

de la Fuente, B. (1995). Teotihuacán, in: La pintura mural prehispánica en México, vol. I, Universidad Nacional Autónoma de México, Instituto de Investigaciones Estéticas, Ciudad de México. 
Goodall, R., J. Hall, R. Viel, R.F Agurcia, H. G. M. Edwards, P.M. Fredericks (2006). Raman microscopic investigation of paint samples from the Rosalila Building, Copan, Honduras, Journal of Raman Spectroscopy 37(10), 1072-1077. https://doi.org/10.1002/jrs.1606

Grissom, C. A. (1986). A study of green earth, in: Feller, R. (ed.), Artists pigments: A handbook of their history and characteristics, 141-167, Archetype Publications, Ontario.

Hosler, D. (1988). Ancient West Mexican Metallurgy: South and Central American origins and West Mexican transformations, American Anthropologist 90(4), 832-855. https://doi.org/10.1525/aa.1988.90.4.02a00040

Lipiec, I., J. Brown, S. Allard, C. Masala, S. Searson, and B. Watts (2016). Fruta Del Norte Project: NI 43-101 Technical Report on Feasibility Study, Lundin Gold Company.

Lubensky, E. H. (1991). The Ferdon collections of prehistoric ceramic vessels and sherds from Esmeraldas Province, Ecuador, Ph.D. Dissertation, Department of Anthropology, University of Missouri-Columbia, Columbia.

Lujan, M. (2018). Pinturas y pintores en Pachacamac: un estudio multidisciplinario del Edificio B15, paper presented at Avances en el Análisis de Cerámica y Pigmentos: Symposio Internacional, Lima.

Machiels, L., D. Garcés, R. Snellings, W. Vilema, F. Morante, C. Paredes, and J. Elsen (2014). Zeolite occurrence and genesis in the Late-Cretaceous Cayo Arc of Coastal Ecuador: Evidence for Zeolite formation in cooling marine pyroclastic flow deposits, Applied Clay Science 87, 108-119. https://doi.org/10.1016/j.clay.2013.10.018

Magaloni, D., R. Newman, L. Balos, V. Castano, R. Pancella, and Y. Fruh (1995). An analysis of Mayan painting techniques at Bonampak, Chiapas, Mexico, MRS Online Proceedings Library Archive 352.

Martín, A. J. (2010). Trade and social complexity in coastal Ecuador from Formative times to European contact, Journal of Field Archaeology 35 (1), 40-57. https://doi.org/10.1179/009346910X12707320296676

Masucci, M. A. (2008). Early regional polities of costal Ecuador, in: H. Silverman and W. Isbell (eds.), Handbook of South American Archaeology, Springer-Verlag, New York City.

Meggers, B. J. (1966). Ecuador, Praeger, New York City.

Morante Carballo, F. E. (2004). Las Zeolitas de la costa de Ecuador (Guayaquil): geología, caracterización y aplicaciones, Ph.D. dissertation, Universidad Politécnica de Madrid, Madrid.

Moreno, R. G., F. Mathis, V. Mazel, M. Dubus, T. Calligaro, and D. Strivay (2008). Discovery and characterization of an unknown blue-green Maya pigment: Veszelyite, Archaeometry 50(4), 658-667. https://doi. org/10.1111/j.1475-4754.2007.00370.x

Profi, S., B. Perdikatsis, and S. E. Filippakis (1977). X-Ray analysis of Greek Bronze Age pigments from Thera (Santorini), Studies in Conservation 22 (3), 107-115. https://doi.org/10.1179/sic.1977.014

Proulx, D. A. (2009). A sourcebook of Nasca Ceramic iconography: Reading a culture through its art, University of Iowa Press, Iowa City.

Reichel-Dolmatoff, G. (1965). Colombia, Praeger, New York City.

Rice, P. M. (2016). Pottery analysis: A sourcebook, Second Edition, University of Chicago Press, Chicago.

Romero Bastidas, M., A. Sánchez Polo, M. Mármol Villarroel, and F. Espinoza Guerra (2018 ). Los pigmentos del desarrollo regional en la costa ecuatoriana: hallazgos de los analisis de laboratorio, in: V. Bravo (ed.) Pigmentos y brillos en la costa del Ecuador precolombino, Museo de Arte Precolombino Casa del Alabado, Quito.

Rousaki, A., C. Vázquez, V. Aldazábal, C. Bellelli, M. C. Calatayud, A. Hajduk, E. Vargas, O. Palacios, P. Vandenabeele and L. Moens (2017). The First use of portable Raman instrumentation for the in situ study of prehistoric rock paintings in Patagonian sites, Journal of Raman Spectroscopy 48(11), 1459-1467. https://doi. org $/ 10.1002 /$ jrs. 5107

Sánchez-Polo, A., S Briceño, A. Jamett, S. Galeas, O. Campaña, V. Guerrero, C.R. Arroyo, A. Debut, D. J. Mowbray, C. Zamora-Ledezma and J. Serrano (2018). An archaeometric characterization of Ecuadorian pottery, Scientific Reports 9(1), 1-11.

Sánchez-Polo, A. (2018). Pigmentos y brillos en la costa del Ecuador precolombino/ Pigments and Sheens on the Coast of Pre-Columbian Ecuador in: V. Bravo (ed.) Pigmentos y brillos en la costa del Ecuador precolombino, 21-53, Museo de Arte Precolombino Casa del Alabado, Quito.

Samano, J. (1987[1534]). Relación de los primeros descubrimientos de Francisco Pizarro y Diego de Almagro, in: M.G Guérin (ed.), Crónicas iniciales de la conquista del Perú, 37-63, Plus Ultra, Buenos Aires.

Scott, D. A. (2011). The La Tolita-Tumaco culture: Master metalsmiths in gold and platinum, Latin American Antiquity 20(1), 65-95.

Simmons, M. P. (1970). The Ceramic sequence from La Carolina, Santa Elena Peninsula, Ecuador, Ph.D. Dissertation, Department of Anthropology, University of Arizona, Tucson.

Strazicich, N. M. (2002). La Quemada’s Pseudo-Cloisonné Tradition, Archaeology Southwest Magazine 16(1), 7. Valdez, F. (1987). Proyecto Arqueológico "La Tolita," 1983-1986, Arqueológico del Museo del Banco Central, Quito. 
Valdez, F. (1992). Symbols, ideology, and the expression of power in La Tolita, Ecuador, in: R. F. Townsend and A. F. Aveni (eds.), The ancient Americas: Art from sacred landscapes, 229-44, Art Institute of Chicago, Prestel Verlag, New York.

Wainwright, I., K. Helwig, M. M. Podestá, and C. Bellelli (2000). Analysis of pigments from rock painting sites in Rio Negro and Chubut Provinces, Arte en las Rocas: Arte rupestre, menhires y piedras de colores en la Argentina, 203-206.

Wright, V., I. A. Meneses, and É. Laval (2015). The origins of mural painting in ancient Peru: Archaeometric preliminary study of the Ventarrón mural paintings, valle de Lambayeque, Heritage Science 3(1), 1-10.

Zeidler, J. A. (1991). Maritime exchange in the Early Formative Period of coastal Ecuador: Geopolitical origins of uneven development, Research in Economic Development 13, 247-68.

Fecha de recepción: 5-8-2019

Fecha de aceptación: 16-12-2019 